\title{
Becoming-player in school-age childcare
}

Eva Kane eva.kane@buv.su.se

Pat Petrie P.Petrie@ioe.ac.uk

\begin{abstract}
The aim of this paper is to explore if some of Deleuze and Guattari's (1980/2004) concepts can contribute to our understanding of "playwork", particularly among the school-age childcare staff required by governing documents to facilitate play in a school setting. The paper presents a reading of transcribed conversations with school-age childcare staff. We map how two staff teams described playing, and the (e)merging thoughts that surfaced during conversations. The reading challenges a dichotomous view of staff as play facilitators and children as players and we explore other possibilities for interpreting the events described by staff. It seems to us that when children and staff play, in the assemblage of the school-age childcare settings, they do schooling and playing simultaneously, overcoming the dichotomies apparent in educational policy.
\end{abstract}

Key words: School-age childcare, play, playwork, Deleuze and Guattari

Acknowledgements: A special thank you to staff at the participating schools.

\section{Introduction}

Lester and Russell (2010, p.52) argue that, "Playworkers sometimes face difficulties understanding their role as adults in play spaces". To facilitate play is part of the practice of school-age childcare but there is limited research exploring what this might mean to the staff involved (for example, Lester, Fitzpatrick \& Russell, 2014; $\varnothing$ ksnes, 2012, 2013). We have therefore also drawn on research in Early Childhood Education which for some time has provided us with critical and post-humanist accounts of children's play as well as how staff relate to that playing (for example, Barron \& Jones, 2014; Grieshaber \& McArdle, 2010; Sellers, 2010). This paper draws on collaborative Action Research (AR) conducted during 2011-12 with staff in two school-age childcare settings, one in Sweden and one in England. These two groups chose to collaborate in the research (the basis of a PhD study), which focused on play in school-age childcare. The work developed into a two-year long AR project with diverse and multiple forces acting on/in/through it. The project provided a space for staffs' own explorations and resources around theory and practice as well as aiming to contribute to understandings about play in school. This paper looks at one aspect of the work: staffs (e)merging talk about playing in a setting located in school premises and within the formal educational ethos of the school.

A tentative first exploration of the conversations reported here was based on a more structured approach undertaken in earlier research on play facilitation (Kane, Ljusberg \& Larsson, 2013). For this, we traced staffs approaches to play onto a grid of didactic intentions. Interesting as it was, this did not however seem to us to represent the way that the staff described their experiences. It was as 
though in tracing their responses onto a grid, staffs' lived experience evaporated through our fingers, because the grid presented staff as motivated by theory rather than by playing itself, a motivation which had certainly been apparent in our conversations. We needed a different approach, one that did not block out the intensities of emotions and experiences sometimes revealed by staff. Deleuze and Guattari's (1980/2004) concepts of striated/smooth space and de- \& re- territorialization appeared to be better suited to exploring how staff negotiated the demands and regulations of the school, while at the same time opening up a space for children to be, and further become, players.

In this paper we start by introducing the settings we have collaborated with and outline the rhizomatic reading that we have attempted. We read the material arising from the research with reference to the above concepts and to earlier research, in order to explore how staff spoke about play in school. We tried to resist binary understandings by allowing the multiplicities inherent in of staffs' thinking and talking about play in school, to surface.

\section{Material}

Two staff groups were collaborating with us in the Action Research project, independent of each other. One group was employed in a Swedish and one in an English setting, with provision referred to in England as out-of-school or, sometimes, school-age childcare services and in Sweden as fritidshem (literally free-time homes, often translated as leisure-time centres). We shall often refer to both as "settings". Both English and Swedish educational policies hold that one of their roles is to provide for children's play, in a broad educational context (Ofsted, 2001, p. 14; The Swedish National Agency for Education 2007, p. 23; 2011, p. 11). The people staffing them are involved in a common task: reconciling play and education and known as playworkers in England and (literally) free-time pedagogues in Sweden: we mostly refer to both as "staff".

This paper is based on transcripts of conversations held with the two groups of staff in the school-age childcare settings who collaborated with us in the Action Research project, 2011-2012, focussing on play.

\begin{tabular}{|l|l|l|l|l|}
\hline $\begin{array}{l}\text { Table } 1 . \\
\text { Staff and children in the two settings }\end{array}$ \\
\hline & $\begin{array}{l}\text { Age of } \\
\text { children }\end{array}$ & $\begin{array}{l}\text { No of children in } \\
\text { daily attendance }\end{array}$ & $\begin{array}{l}\text { Female staff } \\
\text { Anonymised }\end{array}$ & $\begin{array}{l}\text { Male staff } \\
\text { Anonymised }\end{array}$ \\
\hline Sweden & $10-12$ & 30 & Helena \& Rosie & Axel \\
\hline England & $5-12$ & 25 & $\begin{array}{l}\text { Natasha, Vicky, } \\
\text { Tanya }\end{array}$ & Bill, David \\
\hline
\end{tabular}

Table 1. Staff and children in the two setting

The material arising from the three Swedish staff entailed thirteen conversations, approximately 18 hours overall, the majority of them over a four month period. In the English setting, there were two initial weeklong visits, mainly to build working relationships. These were followed, one year later, by four conversations with two staff members and two debriefs after sessions with children for all five staff, entailing approximately $7 \frac{1}{2}$ hours of recordings.

The conversations were transcribed in the language spoken. We read the transcriptions in the original language, but translated, as appropriate, from Swedish into English for quotations used in this paper. The quotations are presented in the paper in a simplified form (see Linell, 1994) for the purpose of readability; they include original pauses (in round brackets), overlapping speech [in square brackets]. Researcher's comments are in \{curly brackets\}. In referencing the quotations, the date is supplied as well as the country and the name of the staff member. 


\section{Rhizomatic reading}

The following reading is an attempt at a rhizomatic reading that "embraces complexity and chaos and attempts to find ways to map it" (McNaughton, 2004, p. 99). Our initial feelings when engaging with Deleuze and Guattari's (1980/2004) concepts were confusion. The attempt to disturb common sense understandings opened up a messy, intense web of connectedness and yet it was exciting. We allowed the transcripts to speak to our emotions and 'plug in' to our circuits (St. Pierre, 2008, p. 183) and used concepts that "worked" for us, as we attuned to energies and feelings. "This second way of reading's intensive: something comes through or it doesn't" (Deleuze, 1995, p. 8). With staff, we tried to find spaces of intensity, apparent in the audio recordings when contributors became emotionally involved, and others were drawn into that involvement, as evidenced by overlapping speech and supporting statements (Linell, 1994, p. 10).

Lodge yourself on a stratum, experiment with the opportunities that it offers, find an advantageous place on it, find potential movements of deterrorialization, possible lines of flight, experience them, produce flow conjunctions here and there, try out continuums of intensities segments by segments... (Deleuze \& Guattari, 1980/2004, p. 178).

Both in conversations with collaborators during the project and in our reading of the transcripts, we allowed our presence to surface; we lodged ourselves on a stratum and tried to be sensitive to possible lines of flight. When reading the transcripts we focused especially on (e)merging thoughts, open-endedness, metaphors and when contributions refer back to earlier contributions. It was very difficult to avoid binaries but what slowly emerged were possibilities for resisting arboretic and linear logic and instead allowing the messiness of researcher-collaborators-play-staff-children-schoolplayers (to name just a few) to speak to us.

It has been important for us to keep our focus on the staff and how we talked about play and playing rather than what the children did when playing. According to Semetsky (2008, p. viii) concepts are for Deleuze and Guattari "a vehicle for expressing an event, or becoming". In this paper we use their concepts to map the staffs' becoming-players.

\section{Schooling and Playworking}

Schools are institutions governed by law, which, by default, suggests a structured environment. They are institutions based on principles of regulating, measuring, controlling and dichotomies such as adult/child, teacher/pupil, work/play, right/wrong etc. (Johansson, 2011; $\varnothing$ ksnes, 2012, p. 7). This is the kind of arboretic logic that Deleuze and Guattari (1980/2004) argue prevails in Western society. It is a logic built on dichotomies where arguments are tree-like, with branching growth (equated to development) and a binary structure, that can be traced back to roots (or causes). They use the term tracing to demonstrate how arboretic logic is used to explain the social and physical world. When we trace knowledge, we create branching dichotomies - an action is to be seen as "either this or that": the option of ambiguity is denied. That is what happened when staffs' conversations about practice initially were traced on a grid (Kane, Ljusberg \& Larsson, 2013). Arboretic logic leads us to stratify or create what Deleuze and Guattari call a striated or boundaried space for meaning. They suggest, accordingly, that in travelling across this kind of striated territory, social or otherwise, it is only possible to go down prescribed paths, in already defined ways. In an educational context Kemmis calls this schooling that "domesticates 'to existing social, economic and discursive orders'" (2006, p.465).

Commentators in both England and Sweden have described facilitating play in an outcome-focused learning environment as paradoxical (Halvars Franzén, 2010; Henry Smith, 2010; Kane et al., 2013). The image of the child in the educational policy of both countries can be seen as ambiguous, 
highlighting children's agency as well as their need either for adult protection or correction. An example of this contradictory message may be found in the general guidelines on what constitutes quality in leisure-time centres (The Swedish National Agency for Education, 2007, p. 23) where one section opens with a view of children as competent actors: "Children are constantly and actively creating their own development and their own learning during play..." Later the same section proposes a different view of children: "With regard to supporting and stimulating children's development and learning, the presence of adults can be required when children are involved in free play." Grieshaber \& McArdle (2010) critically explore the common sense understanding of children's play as natural, innocent, fun and developmental. They ask questions about this capturing of children's play that produces staff who encourage and facilitate "nice" play and close down all types of play that do not align with this common sense understanding. The spaces of schooling "magically capture us", what is best for school and society is also, magically, the individual's desire (Deleuze \& Guattari, 1980/2004, p.471). Seen in this light, schooling produces play as something children do to learn and as something that staff should facilitate.

In England, playwork practice and education has developed out of the adventure playground movement with an emphasis on children's right to play, and with the provision and its staff compensating for diminishing play opportunities for children in society at large (Wilson, 2009). The English peer-led education and training field developed Playwork Principles to clarify the focus of such work. Principle number 4 reads:

For playworkers, the play process takes precedence and playworkers act as advocates for play when engaging with adult led agendas (Playwork Principles Scrutiny Group, 2005).

The practice of playwork can be seen as a binary opposite to schooling in a Deleuze and Guattari reading, what emerges is another striated space with its own boundaried space for meaning. The prescribed paths to follow are to resist "adult agendas" and see play as an innate impulse that children require time and space to express in their own way without adult intervention or "adulteration" (Wilson, 2009, p.7). The role of staff is "to support all children and young people in the creation of a space in which they can play." (Playwork Principles Scrutiny Group, 2005). Playworking in this case produces play as a process children engage in to survive and develop, and something staff should facilitate.

\section{Schooling and Playworking as dichotomous spaces}

Our collaborators often focused, explicitly and implicitly, on schooling as simply a limiting, regulating and restricting force. The implicit references were often noticeable in how the Swedish staff talked about the fritidshem and entailed the school's restrictions on how they structured their work, with set times for certain activities and snacks.

Axel: $\quad$ It becomes like these kind of (R: yes) small blocks, the time they spend here. (Sweden 31/8).

The more explicit references to schools as a regulated space included references to rules and values that staff seemed to think forced them or the children to do things in certain ways. This was common in both the Swedish and English setting.

Vicky: I put the benefits of play on the school risk assessment \{form\}, that there isn't a space for, so, whether they will accept that as a, you've got the box \{on the assessment form $\}$ of what measure have you got in place (Researcher: $\mathrm{mm}$ ) to 
prevent hazards (Researcher: $\mathrm{mm}$ ) and one of them is, I've put the benefits of play as a as a way of preventing the hazard...

Researcher: and you couldn't add a box?

Vicky: $\quad$ No. Because I can't [change].

Researcher: $\quad[\mathrm{hm}$ the form].

Vicky: $\quad$ it has to be the form that (Researcher: yeah) they do \{produce

(England 25/9).

The English staff discussed their role as playworkers as not being about "socializing" children. This seemed to mean that imposing conventional rules was antithetical to playing, indicating that when staff believed that in their interactions with children they acted as staff, they "socialised" the children. The existing order in this setting actually predated the school's taking over its management and was aligned with Playwork Principles (above). This opened up the possibility for staff in the English setting of having to negotiate different stratifying forces.

Vicky: $\quad$...we had that, because it's such a strong playwork thing, we had that guideline of you don't need to encourage, you know you don't get the children to clear up afterwards because it's this and because it's this and there was a reasoning behind it [(Natasha: $\mathrm{mm}$ ) (Researcher: $\mathrm{m})$ ] but what I'm saying you know we don't have to stick to that if that doesn't work in the space

(England 26/9).

In their talk about school and playwork, it seemed to us as if staff identified events that we understood as trapped in the previously described dichotomies. We realised that we needed to disturb our thinking about play to move away from the dichotomies inherent in both schooling and of playworking. From this perspective, we explore what, if any, is the distinctive contribution of Deleuze and Guattari's concepts to our understanding of playing in a school setting? How can we understand talk about play and playing, not by accepting arboreal binaries, but by avoiding or resisting them? It is only in doing so that we may discover what Deleuze and Guattari have to offer.

\section{Playing as becoming-different}

While staff talked about schooling as a restrictive force, play was discussed as a life-giving force. One staff member described a life without play as "walking through life with a blindfold" (Sweden 18/1 Axel) and argued that playing enabled you to explore the combined experience of emotions, relationships and the physical. They used the example of tree climbing: what it feels like to look down from the tree, to hold on to it when it is blowy ... or maybe the climber pretends to be climbing Mount Everest and gets imaginatively close to that experience. As we engaged with Deleuze and Guattari (1980/2004) we explored the possibility of moving beyond trying to define play, since this seemed to lead us to categorizations and binaries such as those expressed above.

Play as subject, playing as activity is one and the same - elusive. It's not that one is immanent to the other, each is the other. On this flattened plane, play and playing collapse into fragmentary wholes (Sellers \& Chancellor, 2013, p. 301).

In our reading, we foregrounded "playing" in order to disturb our thinking. Harker (2005, p.53) suggests: "... playing occurs at the intersection of being and becoming. It has no identity (being) except as a secondary characteristic of its ontological difference (becoming)." Barron \& Jones (2014, p. 8), inspired by Deleuze, open up an understanding of playing as becoming, not as in "becoming adult", with the finality that phrase suggests, but as a way of understanding that we are never fixed or finished, that every moment and relationship (with people, animals, plants or things) carries new possibilities. 
An English staff member (26/9 Natasha) recalled approaching a boy hanging from a high branch in a tree and seeing him let go and jump down. When she affirmed his action he gave her a big hug! The child dared to jump while the staff resisted stepping in and stopping a possibly dangerous activity and was elated to see the boy's achievement. In considering this situation we may hear the staff speak of a co-creation by the boy and herself, in the becoming of brave risk-taking players. Lester (2013b, p. 131) writes: "children's play marks a time/space in which ever-present virtualities are actualised, producing moments in which children are becoming-different." In the story, above, of the becoming of brave risk-taking players both the child and the staff entered the time/space that allowed each other to "become-different"!

Playing can be understood as minor or voiceless politics, opening up moments of "resilience, reworkings and resistance" (Lester, 2013a, p. 38); lines of flight that subvert the related binaries of adult/child. Playing disturbs order and "overcome [s] molar, common sense and habitual constraints..." (Lester, 2013a, p. 32). In school-age childcare this can be seen as resistance to the "centripetal forces" of schooling. Øksnes (2012) exploring children's "escape routes", or lines of flight in school-age childcare, found that children never completely rebelled against the context but used it as material for their own fun.

In this paper we conceptualise playing not as a fixed phenomenon, subject to laid-down criteria, but rather as a way of being, "as a time-space that disorders the real world, play may also offer the opportunity to move beyond existing ways of being" (Lester \& Russell, 2010, p. 10) or in Deleuze terms, of becoming. Playing events open up space for becoming-different for both staff and children.

\section{School-age childcare as both striated and smooth spaces}

Deleuze and Guattari contrast the tree with the rhizome; which suggests multiplicities, rather than the binaries of arboreal logic. As a broken rhizome grows, it often multiplies, sending new shoots in new directions and it "assumes very diverse forms" (Deleuze \& Guattari, 1980/2004, p. 7). The rhizome becomes: like an oil spill, it finds cracks and seeps through and around structures, connecting the most unlikely spaces and places, endlessly changing. These connections may be called lines of flight or a "celebration of the opening up of the not-yet-known" (Davies, 2012, p. 15). The lines of flight access open or smooth spaces as opposed to striated, pre-structured spaces. The multiplicities of smooth space are not "observable from a point in space external to them" (Deleuze \& Guattari, 1980/2004, p. 409). We understand this to mean that they have to be experienced. It is this insider experience conveyed by staffs' accounts of being a different kind of adult in the school.

Vicky: $\quad$... we are seen as the adult (Researcher: $\mathrm{mm}$ ) so when we react, and especially, you know with the children, when you react in a way that they don't expect an adult to react you get kind of a (Researcher: $\mathrm{mm}$ ) that, uh (Natasha: yeah, oh my god, yeah) woo, so I walked through school and the kids all see me, you know in school-time.

Natasha: [yeah]

Researcher: [yeah]

Vicky: $\quad$ and the kids will see me and l'll walk along and just stick my tongue out at them (Natasha: yeah!) with a big smile and watching their reaction is brilliant (Researcher: $\mathrm{mm}$ ) because some of them laugh and kind of haha and others are just kind of like, they don't quite know.

Natasha: [what to do]

Vicky: [how to take it]

(England 26/9).

Deleuze and Guattari argue that it is only in relationship with the strata that lines of flight can be freed (1980/2004, p. 178). We understand the staff's tongue gesture in the above example as an 
"agent of deterritorialization" (Deleuze \& Guattari, 1980/2004, p. 358). A different possibility is for play staff to territorialise by aligning with the striated social order of schooling. We can imagine the children calling a staff member who does so "Miss" or "Sir" and their behaving towards the children like a teacher. In doing so they would become-the-same, performing as expected (Johansson, 2011, p. 12). Or, if like Vicky, they open themselves up to playing, we can imagine the children calling them by their first names and their not performing in line with expectations: they become-different.

Deleuze \& Guattari suggest that assemblages in striated spaces can support the strata or open up lines of flight to smooth spaces (1980/2004, p. 556). The assemblage: staff-tongue-children, in this case opened up a line of flight.

The English staffs were concerned about the lack of resources in their setting possibly due to a general lack of care for them. As part of the conversation we discussed if what they were concerned about can be called inappropriate use, as in use that damaged resources.

Vicky: $\quad$... cause they're not playing, like, what, defines that action to you so that it wasn't being played with? Why isn't walking through the room and kicking something on the floor play? ( ) it's an impulsive ( ) something that's come from internally, cause it, creates a sense of pleasure, (Natasha: $\mathrm{mm}$ ) or not pleasure or you know emotes, how is that not play?... How do you know it's not play? That's you know.

Natasha:

Vicky:

Natasha:

Vicky: [and you]

[that's_why] we haven't reacted upon it ( ) so which is we are defining what misuse is to the point of creating.

yeah but if you argue that point any [thing could be play]

The staff seemed to be exploring the concept of play. According to the Playwork principle number 3 (Playwork Principles Scrutiny Group, 2005), staff should facilitate and support the play process. We understand this attempt at prescription as to how staff should behave regarding play, pinning it down, as stratification. Here, staff seemed to be describing a child's (possibly) smooth space as it occurred in their own stratified space. It seemed that both play as subject and playing as activity escaped their categorisation (Sellers \& Chancellor, 2013, p. 301). Here the assemblage of hat-kickfloor affords a conversation on the threshold of the playing child and the playworking adult.

With Deleuze and Guattari's (1980/2004) concepts, school-age childcare opens up into multiple spaces, striated and smooth, full of schooling, playworking and playing.

\section{Playing as re- and de-territorialization}

Deleuze and Guattari (1980/2004) suggest that striation and smoothness are dependent on each other "Every rhizome contains lines of segmentarity according to which it is stratified, territorialized, organized, signified, attributed, etc., as well as lines of deterritorialization down which it constantly flees." (p. 10). When reading the transcripts with these concepts a constant flow of re- and deterritorialization of spaces emerged. Staff in the Swedish setting offered the children what has been termed a "playframe". The term is defined by Else $(2008$, p. 80 ) as a physical space and Guilbaud (2003, p. 10) adds the idea of the playframe as a narrative. Staff removed all the equipment from the play space, put it in one room and told the children that they had to earn currency to buy it from "the market". The currency was acorns, which children earned as payments for playful tasks such as blowing their nose or finding the shortest way to the dining hall. When the children started cheating, by going outdoors for their own acorns, a staff member first joined them and then, suddenly, decided to steal acorns from the staff "currency lady". When the currency lady called for help, some children quickly took on the roles of policemen, bodyguards, lawyers and prison guards and the playframe 
grew. The thieving staff member was imprisoned and guarded by a girl who was concerned about the thief's behaviour, and tried to have a discussion about it. The staff member said:

Rosie: $\quad$ yes it was fun, and then I had guards the whole time, a girl (Researcher: yes) she tried to get me to change my view about work (Researcher: $\mathrm{mm}$ ) and I thought it was funny because she stood there with notes like this, "if you see someone coming on the street with money like this, what do you do?" "I take them!" I said (Researcher: hmm laughs) (Rosie: laughs herself)"But they are not yours!" "But then they become mine!" I said and she tried (Researcher: laughs) with [all].

Helena:

Rosie: $\quad$ yes to try and get me on a better...

Researcher: but how interesting

Rosie: $\quad$ yes so she, the whole time she was trying to change my mind, and I stole, because those stupid people came with the bucket of acorns like this so I... (laughs)

(Sweden 5/10).

Staff deterritorialized the space by changing the usual features of the play space (removing equipment) while at the same time reterritorialising the space through signalling, by means of play cues (a meta-communication that lets us know that 'this is play' [Bateson, 1972]), that this was a playframe, a territory with its own rules and regulations (rules about buying back equipment and earning currency). Some players accepted the striation and abided by the rules (buying back equipment rather than just removing it from where it was stored) and some rhizomatically found another way to deterritorialized the space by breaking the "rules" (finding more acorns). Some children also reterritorialized the space (created a prison) for the staff member who was ignoring boundaries and in that space attempted to make the staff prisoner acknowledge and submit to the rules of the territory (the playframe).

Playing entails multiplicities, connecting diverse meanings where children and staff connect with both striation and smoothness in a seamless flow of interaction. Lines of flight may only be possible if there is a stratified space to resist and, as in the example, a space emerges where both staff and children are playing and continuously de- and re- territorialise.

\section{Resisting capture}

When exploring schooling, playworking and playing as simultaneous, we also found examples where staffs were struggling to avoid being captured by either schooling or playworking. "Strata are acts of capture...They operate by coding and territorialization..." (Deleuze \& Guattari, 1980/2004, p.45). Both groups of staff, but most often the English staff, came back to something they tended to call 'their play', often referring to children's playing that was problematic for staff.

Natasha: I would, yeah I would say, that's what it is, it's it's those people who like to manipulate their surroundings and their knowings to bett $\{\mathrm{er}\}$, to help them basically, to get them further into whatever they want to be, or whatever they want to do or what they are doing at that precise moment () but also it could be their play, you know, that's the other thing that always ( ) is there is the fact that, and we have spoken about it (Vicky: yeah) a few times, that ( ) actually maybe that's that's their play, that's how they want to play that's what they want to do, there is no read in to it, they just want to play, that's so that's how they are, that's what they want to do

(England 25/9). 
'Their play' seemed to be a way to talk about how some children's play is unconducive to the wishes and needs of others or takes little note of limited equipment and materials, or of how, from the point of view of school leadership, they should be used. Staff provided some examples of this such as below:

Natasha: $\quad$... she chucked the bike on the floor, then I felt like I was just like "aaaaah", really annoying \{Natasha has a giggly voice here\} because I've spoken to them so many times, and I think that I should go and talk to her but in the end I just left it (Vicky: $\mathrm{mm}$ ) because she went off (Vicky: $\mathrm{mm}$ ) so I thought there was no point to try and stop her (Vicky: $\mathrm{mm}$ ) she looked at me as well (Vicky: $\mathrm{mm}$ ) which I think annoyed me even more cause [the fact is she new]

(England 26/9).

Natasha seems here to be talking about how she is drawn into what Johansson $(2011, p .4)$ calls becoming-the-same, adults re-establishing the existing order. In this case there is a rule that the children need to be careful with the bikes since they do not have that many unbroken usable bikes left. The intensity conveyed in Natasha's giggle might suggest that something else is also going on. As a playworker she should support the child's play and not make interventions based on adult agendas. The existing order in this case was "playworking". We understand the term "their play" as reterritorialising playworking. Possibly a way of reminding herself that her job was in fact to support children's play and prioritise it above adult agendas.

Natasha's response to the girl chucking the bike on the floor seemed to open up messy assemblages, which left her struggling with stratifying forces operating across different striated spaces without apparent access to lines of flight and smooth space. Deleuze and Guattari's concept of stratification opens up the multiplicity to be found in these settings, with schooling as well as playworking producing strata that staff find hard to negotiate.

\section{Playing - saying yes to lines of flight}

At the core of Deleuze and Guattari's (1980/2004) practical philosophy is the idea that thinking and knowledge are not hierarchical or linear, instead they are unpredictable, random, resilient and full of life. Events, and Deleuze argues that thinking is an event (Colebrook, 2010), connect diverse meanings and multiplicities to each other through lines of flight. When discussing the outcomes of the Action Research one member of staff put it this way:

Axel: $\quad \quad \quad \quad \quad \quad$ what has happened for me it is that one sees these small nuances more and then you get so many doors that you can open, that they \{children\} play this, right!, shit, I haven't seen that before, and he plays this and then you could do this based on his little idea, what he is doing or, yes you could elaborate on so many more things than what you thought before because you didn't see them, so you just kind of, you see many more things that are possible to do...

(Sweden 18/1).

The staff member's speech was marked by excitement or intensity. We suggest that they were saying that lines of flight ("doors" in their own terms) had become visible, they had seen many possible ways for playing to seep through, into and between structures, finding unexpected ways of becoming-player. 
Axel: $\quad$... play is part of all levels of human development and activity, I would say, scientists, all their theories about the universe are basically playful... like an engine...

Rosie: $\quad$ I agree with that (Helena: $\mathrm{mm}$ !)

Axel: $\quad$... this exploration, of different bits of the puzzle and what happens if I do this, what happens if I take $A$ and $B$, what happens if I take $A$ and $C$, what happens if I take $A$ and $Z$ and so you build and things become...

(Sweden 18/1).

The staff seemed to say that, in the terms of Deleuze and Guattari, playing could be seen as an engine propelling staff and children along lines of flight: the engine as a flow of "reactions" or intensities in a constant becoming-different; the playing as an assemblage of "different bits of the puzzle", connecting "inside and outside" and "A \& Z", a machine within a concrete assemblage (Deleuze \& Guattari, 1980/2004, p. 562) that constitutes the becoming-different.

Helena said: "Without playing you die. Inside!" (Sweden 18/1). This type of death may well be the "stultifying suffocation" that Davies (2012, p. 12) identified as an emotion to be found in stratified space. Yet Deleuze and Guattari argue that it is only in relationship with the strata that lines of flight can be freed (1980/2004, p. 178). When staff (and children) opens themselves up to continuously deand re- territorialise spaces they allow intensities to flow.

Rosie: $\quad$ no, but can you not just say that you think that you have done something fun together with the children, something unusual and fun, that is what I think you... that's just that (Researcher: $\mathrm{mm}$ ) that is what happens, has happened that we made it fun and had fun the whole time $(\mathrm{H}: \mathrm{mm})$ but I'm not saying that it isn't fun at other times but this is special (Researcher: $\mathrm{mm}$ ) I think that's enough (Researcher: $\mathrm{mm}$ ) it's enough.

(Sweden 5/10).

Here the speaker is reflecting on the intensities available in playing. To say yes to the line of flight is to momentarily escape the habitual constraints, the schooling, the playworking and "to leave room for the otherness of children and their affective dis-orderings that disturb the taken-for-granted" (Lester, 2013a, p. 37). To have fun together is opening up to the possibility of "cosmic events", of becoming-different.

\section{Becoming-player}

In the Swedish setting computer use was regulated by the staff. Computers could be used for $30 \mathrm{~min}$ at a time. The children were said to value computer time and put themselves on the list to ensure their turn. When staff observed children at the computers they suggested that what was going on there was not, as they had previously thought, limited to individual computer gaming use there was playing too.

Axel: $\quad$ They can sit at a computer and seemingly play a computer game, but then the two sit, stop and look, they play with each other really and the computer is just there, kind of, in some way, it can be about roles, status, or pretend that you are in a certain way...

Rosie: the computer is the..., basis [for it].

Axel: [it's not] the game in the computer that is in focus really, it's kind of a background carpet, a little noise.

(Sweden 18/1). 
Rhizome growth is hard to stop, if broken it grows new shoots; faced with a barrier it finds the tiniest of cracks to grow through. Staffs talk about children playing and moving effortlessly between different territories. The children playing the computer games seem to be simultaneously playing with each other, deterritorialising and reterritorializing the in-between spaces. Staffs now seem to see the children not as computer users but rather as becoming-players.

We find simultaneity also when staffs talk about their own actions. When children approached them, a member of staff would recognise whether the approach was part of a playframe and, as appropriate, enter into playing rather than "being a member of staff that \{merely\} answers" (Sweden 18/1 Helena). The staff member was aware of play cues, the meta-communications signalling; "this is play" (Bateson, 1972). They seemed able to recognise what Deleuze and Guattari would term lines of flight offered by the children and seemingly resist the normative behaviour of schooling or playworking. It is as if, in detecting the playing, staff acknowledge the "microscopic event [that] upsets the local balance of power" (Deleuze \& Guattari 1980/2004, p. 15) opening up space for both children and staff to become-players.

At the same time, something else entirely is going on: not imitation at all but a capture of code, surplus value of code, an increase in valence, a veritable becoming, a becoming-wasp of the orchid and a becoming-orchid of the wasp. (Deleuze \& Guattari, 1980/2004, p. 11)

The line of flight is the connectedness between the striated and the smooth space and they are dependent on each other. When children hit staff, staff can stay in the striated space of schooling where this is seen as an offence or they can accept the offering of a line of flight and become-player "they come and hit me and then I'm supposed to hit back" (Sweden 18/1 Rosie). Staff are both schooling and playworking (when risk assessing for example) and becoming-player in a seamless flow between striated and smooth space with the children. "It is about allowing yourself to become anew with each event, and to be affirmative of learning as a state of transformation" (Lenz Taguchi, 2010, p. 94). This becoming anew is allowing the self to flow along lines of flight as opportunity arises and, in the settings under consideration, to become-player with the children. Staff provided vivid examples of this:

Natasha: I get involved with () water fights predominantly ( ) because they get me wet first and then I have to get them wet, but its play you know, that's what I'm good at, I'm good at being ( ) a ( ) play object.

(England 8/9).

Equally staff recounted stories of how a moment later they reterritorialized the space.

Natasha: $\quad$... they would become the one that we were chasing and ( ) if somebody got hurt or something was happening I'd say to them, well what do you want to do like, do you want to make up some rules or do you want to ( ) stop.

(England 8/9).

Sometimes staff seems to flow effortlessly between becoming-player, schooling and playworking in a space of potentiality and movement.

\section{Conclusion}

We set out to explore if Deleuze and Guattari's (1980/2004) concepts could contribute to our understanding of playwork in a school setting. Applying the Deleuzian concept of striated and smooth spaces in exploring play in school-age childcare, revealed messy multiplicities. While 
schooling suggests a striated space, where only certain types of play and playing were permissible (hence the adult presence), playworking suggests another striation, which regulated the staff's behaviour more than the children's. One of them, Vicky, acknowledged this when she said, "there was a reasoning behind it" - that is, certain logic lay behind the non-intervention expectations of the English Playwork Principles.

Playing, on the other hand, implies smooth space with "microscopic event [that] upsets the local balance of power" (Deleuze and Guattari, 1980/2004, p. 16) and challenges the dominance of both schooling and playworking. Using concepts from Deleuze and Guattari (1980/2004) allows us to understand that words applied to playwork in policy documents, words like facilitation and support are terms that re-activate dualisms such as child/adult, enabler/unable and suggest that playing may not happen without staff support and facilitation. Yet in our reading both children and staff where playing. We understand staff members as well as children to be, at the same time, part of the strata and of the smooth space and staff seemed to suggest that this was what made their work enjoyable. We proposed earlier that children and staff were in a continuous state of becoming when they were together in the school and sometimes they become-players together. In the words of Davies (2012) we need striation and flight to produce new realities. Sometimes staff provides striation and sometimes children; equally both staff and children can open up smooth space and invite others to become-players. Becoming-players together provide moments of intensities, simultaneously moving between what is and what might become, producing new realities for children and staff. What Deleuze and Guattari's concepts have allowed us to see is that in school staff can do schooling, playworking and playing simultaneously, overcoming the dichotomies apparent in policy.

We have come to understand playing as an engine - a machinic assemblage of people and things, emotions and thoughts, doings and saying, parts and wholes connected to each other in the intensity of the moment, willing to enter into the spirit of becoming-different and in so doing resisting schooling and playworking to become-players. Deterritorializing events (Deleuze \& Guattari, $19080 / 2004$, p. 358) of becoming-players can be initiated by anyone or any event in the assemblage of the school-age childcare setting.

\section{References}

Barron, I., \& Jones, L. (2014). Performing Child(hood). Children \& Society, 28, 257-268. http://dx.doi.org/10.1111/j.1099-0860.2012.00453.x

Colebrook, C. (2010). Gilles Deleuze en introduktion. Göteborg: Korpen.

Davies, B. (2012). Normalization and Emotion. Paper presented at Mid-Sweden University Sundsvall Oct.

Deleuze, G. (1995). Negotiations. 1972-1990. Chichester, NY: Columbia University Press.

Deleuze, G., \& Guattari, F. (1980/2004). A thousand plateaus: Capitalism and schizophrenia. (B. Massumi, Trans.). London: Continuum. (Original work published in French 1980).

Else, P. (2008). Playing: the space between. In F. Brown \& C. Taylor (Eds.), Foundations of Playwork (pp. 79-83). Maidenhead: Open University Press, McGraw Hill.

Grieshaber, S. J., \& McArdle, F. (2010). The Trouble with Play. Maidenhead, England: Open University Press.

Guilbaud, S. (2003). The essence of play. In F. Brown (Ed.). Playwork. Theory and Practice (pp. 9-17). Buckingham: Open University Press.

Halvars-Franzén, B. (2010). Barn och etik: Möten och möjlighetsvillkor i två förskoleklassers vardag. [Children and Ethics: Ethical Encounters and Conditions in the Everyday Life of Two Preschool Classes]. PhD Thesis, Stockholm University, Sweden.

Harker, C. (2005). Playing and affective time-spaces. Children's Geographies. 3(1), 47-62. http://dx.doi.org/10.1080/14733280500037182 
Henry Smith, H. (2010). Children's empowerment, Play and Informal Learning in Two After School Provisions, PhD Thesis, Middlesex University, UK.

Johansson, B. (2011). Doing adulthood in childhood research. Childhood, 19(1), 101-114. http://dx.doi.org/10.1177/0907568211408362

Kane, E., Ljusberg, A-L., \& Larsson, H. (2013). Making magic soup: The facilitation of play in schoolage childcare. International Journal of Play, 2(1), 7-21. http://dx.doi.org/10.1080/21594937.2013.769814

Kemmis, S. (2006). "Participatory Action Research and the Public Sphere." Educational Action Research, 14(4), 459-476.

Lenz Taguchi, H. (2010). Going beyond the theory/practice divide in early childhood education. Introducing an intra-active pedagogy. Abingdon: Routledge.

Lester, S. (2013a). Rethinking children's participation in democratic processes: A right to play. In S. Kawecka Nenga \& J. K. Taft (Ed.). Youth engagement: The civic-political lives of children and youth (Sociological Studies of Children and Youth, Volume 16) (pp. 21-43). Emerald Group Publishing Limited.

Lester, S. (2013b). Playing in a Deleuzian playground. In E. Ryall, W. Russell \& M. MacLean (Eds.). The Philosophy of play. (pp. 130-140). Abingdon: Routledge.

Lester, S., \& Russell, W. (2010). Children's Right to Play: An Examination of the Importance of Play in the Lives of Children Worldwide. Working Paper No.57. The Hague, The Netherlands: Bernard van Leer Foundation.

Linell, P. (1994). Transkription av tal och samtal: Teori och Praktik [Transcriptions of speech and conversation: Theory and Practice]. (Report from Tema Kommunikation No. 1994:9). Linköping University: Sweden.

McNaughton, G. (2004) The politics of logic in early childhood research: A case of the brain, hard facts, trees and rhizomes. The Australian Educational Researcher, 31 (3), 87-104.

Ofsted (2001). Out of School Care: Guidance to the National Standards. Nottingham: DfES.

Sellers, M. (2010). Re(con)ceiving young children's curricular performativity, International Journal of Qualitative Studies in Education, 23(5), 557-577. http://dx.doi.org/10.1080/09518398.2010.500629

Sellers, M., \& Chancellor, B. (2013). Playing with play(ing): play-fully writing about play. Global Studies of Childhood. 3(3), 297-309. http://dx.doi.org/10.2304/gsch.2013.3.3.297

Semetsky, I. (2008). Nomadic education. Variations on a theme by Deleuze and Guattari. Rotterdam: Sense Publishers.

St. Pierre, E. A. (2008). Deleuzian concepts for education: The subject undone. In I. Semetsky (Ed.). Nomadic education. Variations on a theme by Deleuze and Guattari. (pp. 183-196). Rotterdam: Sense Publishers.

$\emptyset$ ksnes, M. (2013). 'We sneak off to play what we want!' Bakhtin's carnival and children's play. In E. Ryall, W. Russell, \& M. MacLean (Eds.), The Philosophy of play, (pp. 141-151). Abingdon: Routledge.

\section{Electronic resources}

Bateson, G. (1972). A theory of play and fantasy. In: Salen, K. \& Zimmerman, E. (2006) The game design reader. A rules of play anthology. London: MIT press. Available at: http://sashabarab.com/syllabi/games learning/bateson.pdf (accessed 5. July 2013).

Lester, S., Fitzpatrick, J., \& Russell, W. (2014). Co-creating an Adventure Playground (CAP): Reading playwork stories, practices and artefacts. Gloucester: University of Gloucestershire. https://www.academia.edu/7020633/Lester S. Fitzpatrick J. and Russell W. 2014 Cocreating a Play Space reading playwork stories practices and artefacts (accessed 23 June 2014). 
Playwork principles scrutiny group (2005). Playwork principles. Available at: http://www.skillsactive.com/our-sectors/playwork/playwork-principles (accessed 25 June 2013).

The Swedish National Agency for Education (2007). The general guidelines and comments for quality in leisure-time centres. Available at: http://www.skolverket.se/publikationer?id=1810 (accessed 25 June 2013).

The Swedish National Agency for Education (2011). Curriculum for the compulsory school system, the preschool class and the leisure-time centre. Available at: http://www.skolverket.se/publikationer?id=2687 (accessed 25 June 2013).

Wilson, P. (2009). The Playwork Primer. Available at: http://www.ultimateblockparty.com/download/Playwork Primer.pdf (accessed 24 June 2014).

$\varnothing$ ksnes, M. (2012). If there's something we're not allowed to do, we do it so they don't find out. Children's play in after school programs in Norway. In International Council on Children's Play Conference. Tallin, Estonia, 18-19 June 2012. http://www.iccpplay.org/conferencetallinn2012.htm (accessed 5 July 2013). 